\section{ARTICLE}

Lars Wenzel

\section{University of Bradford}

M. Khalid Nadeem Khan and Peter Evans Office for National Statistics

\title{
Capitalising research and development: towards the new System of National Accounts
}

1 p esearch and Development (R\&D) plays a vital role in modern economies through its direct impact on technological development. Advanced knowledge, created through R\&D, increases the ability of the firms to innovate, develop new products, improve existing products, and increase the efficiency of the production process. If business $R \& D$ increases by one per cent, it results in a 10 to 30 per cent increase in production. ${ }^{1}$ Firm level studies show that R\&D based knowledge is useful for a number of years. In this regard, R\&D is like other assets, such as plant and machinery. Yet, expenses on $\mathrm{R} \& \mathrm{D}$ are treated differently in the old SNA. Unlike investment in buildings, plants, and machinery R\&D expenditures are classed as current expenditure on goods and services, used up in the production process.

This inconsistency is identified in the new SNA and the updated international standards on the calculation of economic aggregates, such as Gross Domestic Product (GDP), recognise spending on $\mathrm{R} \& \mathrm{D}$ as an investment activity. Implementing such a change is challenging due to issues regarding the valuation of $R \& D$ assets, depreciation of R\&D capital stock, and possible double counting with existing assets within the SNA. Consequently, as a first step towards capitalisation, countries are encouraged to develop an $\mathrm{R} \& \mathrm{D}$ satellite account. A satellite account presents data in accordance with the principles and guidelines followed in the preparation of National Accounts, but expands the production boundary. For instance, the R\&D satellite account includes R\&D investment in the production boundary of National Accounts extending the concept of capital formation.

ONS published preliminary results on $\mathrm{R} \& \mathrm{D}$ capitalisation in Galindo-Rueda (2007). The capitalisation increased GDP by 1.5 per cent, on average. With useful preliminary results, the work provided a basis to further improve estimation methods and working assumptions. This paper contributes to the capitalisation agenda and improves: a) depreciation assumptions of R\&D stock in the nonmarket sector, b) the calculation of rate-ofreturn, c) initial capital stock estimates, d) calculation of goods and services consumed in the production of $\mathrm{R} \& \mathrm{D}$ ie intermediate consumption, and e) deflators for land and building and 'other current' expenditures. The rest of this paper explains progress on $\mathrm{R} \& \mathrm{D}$ capitalisation, highlights challenging issues, with solutions adopted and direction for further improvement. Subsequently, capitalisation results from 1997-2007 are covered, and finally, conclusion offers a summary and suggestions for future work.

\section{Capital formation and capitalisation of R\&D}

The previous article (Galindo-Rueda, 2007) has extensively covered conceptual issues related to the definition of $R \& D$, treatment of unsuccessful R\&D, overlap with other intangible assets, and treatment of non-market R\&D. Subsequently, Evans et al, (2008) tested how changes in various assumptions affect headline estimates ie GDP, investment, and gross capital formation (GCF). Therefore this paper will 
only focus on the capital formation and capitalisation of R\&D. Diagram 1 shows basic steps of R\&D capitalisation.

In simple terms, $R \& D$ capital is formed when a producer invests in a project that 'increase [s] the stock of knowledge, including knowledge of man, culture and society, and the use of this stock of knowledge to devise new applications.' (OECD, 2002). Economic theory and NA measure capital formation in two ways: gross and net. Gross capital formation (GCF) is the total outlay in each period, on the purchase or own-account production of an R\&D asset which yields a service lasting beyond the period in which it is acquired. Net capital formation measures the balance of gross capital formation after deducting depreciation.
$\mathrm{R} \& \mathrm{D}$ capitalisation is the reallocation of $\mathrm{R} \& \mathrm{D}$ expenditure from current expenditure to investment. Since the capitalisation project is a work-in-progress, the change is tested in a satellite account, before integrating with the NA. The R\&D satellite account focuses only on R\&D and presents comprehensive information without disturbing the main accounts. In fact, the satellite account is an evolving 'mechanism for presenting particular topics as annexes to main National Accounts' (OECD, 2002), and provides necessary freedom to improve methodology. Diagram 2 provides a detailed view of the steps shown in Diagram 1, presenting a schematic view of R\&D's capitalisation (the focus at this stage is only on capitalisation, related issues are covered in detail later).
Each vertical block roughly represents a step of capitalisation. The horizontal box links the capital stock of Land and Buildings (L\&B) and Plant and Machinery (P\&M) with the rest of the account. Estimating R\&D expenditure is the first step of the capitalisation process. Detailed data is collected from the UK Gross Expenditure in R\&D (GERD) ONS data release, in accordance with the Frascati Manual $(\mathrm{FM})^{2}$. However, FM institutional sectors differ from those of the $\mathrm{SNA}^{3}$. Therefore the second step links the FM institutional sectors to the SNA sectors ${ }^{4}$. The third major step is to strip inflation out of the expenditure data to attain real expenditures. At this stage, a parallel step is completed: calculating capital stock, from investment

\section{Diagram 1}

\section{Basic steps for the capitalisation of research and development}

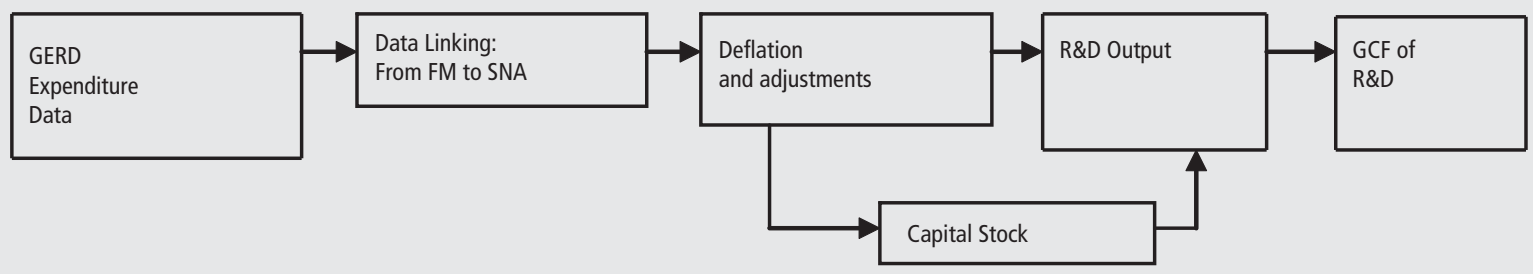

\section{Diagram 2}

\section{Capitalisation of research and development}

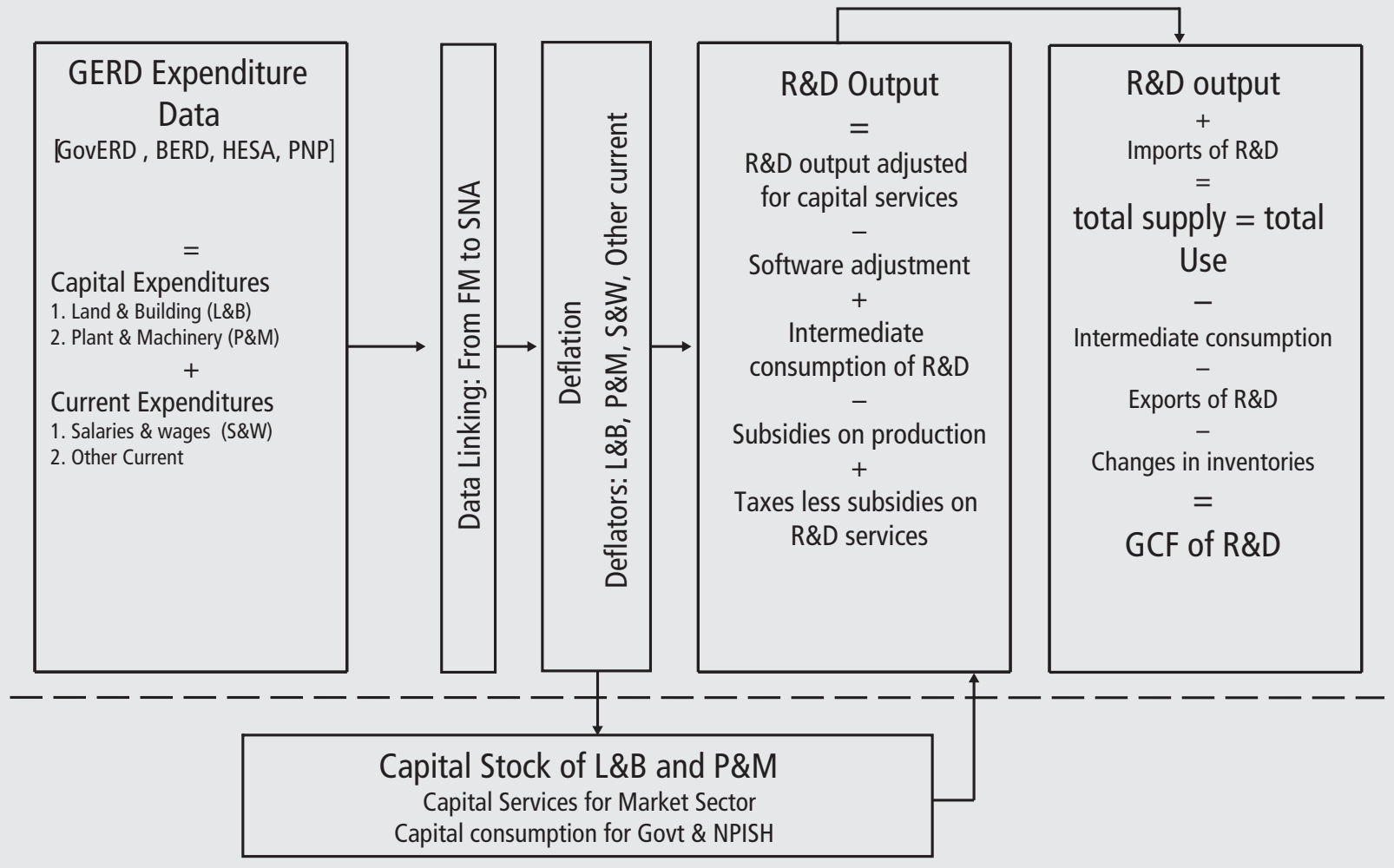

Note:

1 GovERD = Government expenditure on R\&D, BERD = Business expenditure on R\&D, HESA = Higher Education Statistics Agency, PNP = Private-non-Profit, $\mathrm{FM}=$ Frascati Manual, ESA = European System of Accounts, other current = other current expenditure, and GCF $=$ Gross Capital formation. 
data, and capital services. Capital services or capital consumption (in the case of nonmarket sector) replace capital expenditure for the year; R\&D output estimates are adjusted accordingly. The fourth vertical block shows output is the sum of all the costs. Furthermore, output is adjusted for double counting of R\&D in software that has already been capitalised in the software account.

The other three additions to output are: a) other goods and services that are consumed in the production of $R \& D$, including intermediate consumption of $\mathrm{R} \& \mathrm{D}, \mathrm{b}$ ) subsidies on production, and c) taxes less subsidies on R\&D services. Essentially the capitalised output of R\&D is available at this stage, but a further step is required to calculate the supply and use of R\&D. At this stage the production and consumption of rest-of-the-world sector (RoW), ie imports and exports of $\mathrm{R} \& \mathrm{D}$, are accounted for because total available output is the sum of own-produced and imports, and total use is the sum of domestic uses and RoW consumption. The use side also provides information on Gross Capital Formation (GCF), ${ }^{5}$ hence completing the capitalisation process. Further analysis (eg increase in GDP, change in investment, GCF) can be undertaken depending on analytical requirements.

Our schematic presentation simplifies capitalisation. In reality the researcher needs to deal with challenging issues like: R\&D ownership, price of R\&D outputs, economic life length of R\&D assets, R\&D input in the production of other $\mathrm{R} \& \mathrm{D}$ assets, and adjustments for double counting where already capitalised intangible assets that have R\&D components. Decision on these issues affect R\&D output and other headline figures. Below we deal with some of these issues in detail.

\section{Valuation of R\&D}

Earlier articles on R\&D capitalisation have covered the valuation issue in detail and all debates on capitalisation of intangible assets have to grapple with the valuation problem. Since this issue is central to the specific method we have used for capitalisation, we shall cover it briefly. The valuation problem arises because of the difficulty of obtaining price data on R\&D output, due to the majority of $R \& D$ being produced and used in-house. As the price information is not available, monetary value of output is difficult to ascertain.

In this situation, SNA (1993) recommends, that 'the output will usually have to be valued by total costs of production, as is the case with most ownaccount production' (6.164). It is evident that this approach ultimately measures the cost of production not the contribution of $\mathrm{R} \& \mathrm{D}$ assets to productivity, thus ignoring productivity growth. Furthermore, data requirements and quality issues become more consequential as detailed data are required and a complete break down of costs is very difficult to obtain. However, this is the most practical approach for R\&D capitalisation, as all countries have adopted it; it is relatively more practical to implement, and it imposes no new data collection costs, due to widespread interest in $\mathrm{R} \& \mathrm{D}$ ( $\mathrm{FM}$ based surveys provide detailed time series expenditure data on $R \& D$ ).

In the UK the major source of R\&D expenditure data are Gross Expenditure on R\&D (GERD) annual statistical release. The Business Expenditure on R\&D (BERD) collects data on expenditure by activity and divides capital and current expenditure into 'land and buildings', 'plant and machinery', 'salaries and wages' (S\&W) and 'other current' ${ }^{\text {' }}$ expenditures. The Government Expenditure on R\&D survey (GovERD) supplies data on R\&D performance as well as capital and current expenditure on R\&D. Data for NPISH come from Higher Education Statistics Agency (HESA) and private non-profit data are gathered at ONS.

\section{R\&D ownership}

The FM data provide no information on the ownership of R\&D assets. The SNA requirements include identification of economic ownership ('effective management and control of the R\&D output in order to ensure the expected benefits are obtained') for the classification of assets and benefits to an institutional unit. In the absence of an economic owner, benefits from the assets can not be recorded, as is the case with freely available $\mathrm{R} \& \mathrm{D}$. Thus, identification of an owner is necessary for capitalisation.

In the absence of ownership information, the funder, or performer data can determine ownership. For non-market producers, the OECD (2009) recommends that 'the best approach is to use expenditures by socio economic objective (SEO) obtained from performers (i.e. GERD data) for government, higher education and NPIs and transform them to an ownership basis using funding data' (emphasis added). The Bureau of Economic Analysis, United States, deems the funder as the owner of R\&D assets, while Statistics Canada argues the performer is a better base to determine ownership, because of better quality data. Clearly, both approaches have limitations and it is easy to find examples where a funder is not the final owner and similarly a performer does not own the R\&D it performs.

Galindo-Rueda (2007) adopted a clever solution, rather than siding with either the funder or performer approach, he used a mixed approach, based upon ownership shares. He assumes that businesses only fund an R\&D project if they control its benefits through ownership, therefore they retain 100 per cent ownership when they fund projects performed by other businesses, government, and Non-Profit Institutions Serving Housholds (NPISH). However, when they fund a project performed by the rest of the world (RoW), it is considered that the businesses own 90 per cent of it. Since socio economic objectives motivate government decisions, the government may share ownership with the performers. Therefore, when government funds a project that is performed by businesses, NPISH and RoW, it owns 50, 10 and 100 per cent respectively. NPISH fully own the projects they fund, and RoW owns 90 per cent of its funded projects (See Table 1). These assumptions are not final, but are retained for this paper until future improvements can be made, based on new information.

\section{Linking FM data to SNA sectors}

Conceptual differences and different institutional classifications require linking FM data to fit the SNA sectors. Most of the SNA and FM sectors are similar. However, a major difference arises because of separation of the Higher Education (HE) sector in the FM. ${ }^{7}$ In countries with a high proportion of universities in the private sector, HE falls into the Non Profit Institutions Serving Households (NPISH) ${ }^{8}$ but when most of the universities are in the public sector HE is classified as general government. GalindoRueda (2007) determined from classification information that the HE sector should be classified under NPISH. Table 2 shows the linking of the two systems based on OECD (2009) recommendation.

\section{Deflators}

Real expenditures on various components of R\&D are estimated and deflated accordingly. FM indicates that $\mathrm{L} \& \mathrm{~B}$ and $\mathrm{P} \& \mathrm{M}$ absorb a relatively small percentage of R\&D expenditures and proxy deflators are available from the relative class of gross fixed capital formation in the National Accounts. Therefore, we have used 'private commercial construction' deflator for L\&B, and P\&M deflator for P\&M. The other two categories, S\&W and 'other current', have no close comparatives in the NA therefore we have developed composite deflators.

Follow the guideline from the FM we 
Table 1

\section{Share of funder's ownership in R\&D performed}

\begin{tabular}{lrrrr} 
& & \multicolumn{2}{r}{ Funder/Owner Ratio } \\
\hline Performer & Business & Government & NPISH & Rest of World \\
\hline Business & 1 & 0.5 & 1 & 0.9 \\
Government & 1 & 1 & 1 & 0.9 \\
NPISH & 1 & 0.1 & 1 & 0.9 \\
Rest of World & 0.9 & 1 & 1 & 1 \\
\hline
\end{tabular}

Source: Galindo-Rueda (2007)

Table 2

\section{Linking between FM and SNA sectors}

\begin{tabular}{ll}
\hline FM Sector & SNA Sector \\
\hline Government & General Government \\
Research Councils (RC) & General Government \\
Higher Education Funding Councils (HEFC) & General Government \\
Higher Education (HE) & Non-Profit Institution serving Households (NPISH) \\
Private non-Profit (PNP) & Non-Profit Institution serving Households (NPISH) \\
Business Enterprise & Financial, Public and Private non-Financial Corporations \\
Abroad & Rest of the World (RoW) \\
\hline
\end{tabular}

Source: Galindo-Rueda (2007)

have constructed a weighted labour cost deflator, based on salaries data from the Annual Survey of Hours and Earnings (ASHE) and full time equivalent data from BERD. Preparing a deflator for the 'other current' category was relatively challenging because the survey does not provide a breakdown of the type of expenditures included. It is clear from the 'other current' expenditures' definition that services and administrative expenses are included. We have used firm level data in the $\mathrm{R} \& \mathrm{D}$ sector (SIC 73) to determine weights for the relevant class of expenditures that constitute 'other current'. In the composite deflator, the producer price index (PPI) for other goods has a 0.4 weighting and the service PPI for all services has a weighting of 0.6 .

\section{Adjustment for capital services/} consumption and rate of return SNA and FM have conceptually different approaches to the recording of asset. The former measures the cost of capital services/ consumption, which essentially focuses on services/consumption from existing fixed capital. FM records only expenditure (purchases) of new fixed capital. ${ }^{10}$ Therefore the satellite account capital expenditure should be replaced with capital services, for the market sector, and capital consumption for the non-market sector. This step is shown in the Diagram 2 where capital expenditures go into Perpetual Inventory Method and capital services/consumption feed back to R\&D output.

Capital service calculation in a sum-ofcosts method is complicated. This is due to the calculation of the rental rate (see chapter five of the ONS Productivity Handbook, 2007, pp 62-69). The rental rate for the market sector consists of return on capital, depreciation, and capital gain; for the nonmarket sector it includes only depreciation, and therefore capital consumption.

Our composition of the rate of return calculation on capital has been improved. Previously a risk free rate of 4 per cent, per annum, and a 3 per cent fixed inflation rate have been used to estimate the rate of return. In this updated account the risk free return remains the same, but the inflation rate has been replaced with a three year moving average of the consumer price index (CPI), to capture inflation expectations. This rate of return is applied to the market sector only, while a zero rate of return on capital is assumed for the nonmarket sector ie government and NPISH, as recommended by OECD (2009).

\section{$R \& D$ in software}

BERD provides expenditure data on $R \& D$ for 'computer and related activities', which represent 9 per cent of total market sector $\mathrm{R} \& \mathrm{D}$ expenditure. If total expenditures in this category were capitalised in the R\&D satellite account, R\&D in ownaccount software will be counted twice in the UK NA. This is because R\&D in own-account software has already been capitalised in the NA, through the software account (Chamberlin, 2007). One option to avoid this overlap is to take out $R \& D$ in own-account software from the software account. But SNA (1993) recommends that 'expenditure on R\&D does not include the cost of developing software' (3.64). Therefore, it cannot be taken out from the software account and to avoid double counting, should not be included in the R\&D satellite account.
Because the value of software and R\&D within own account software cannot be separated, the extent of double counting is unknown. In the absence of new information, this account follows GalindoRueda's (2007) method and assumes that 50 per cent of intramural R\&D in computer related activities (BBRD/Sector59) is a good proxy for R\&D capitalised in the software account. This adjustment affects the satellite account by $£ 713$ million in 2007 .

\section{Intermediate consumption of other} goods and services

Intermediate consumption 'consists of the value of goods and services consumed as inputs by a process of production, excluding fixed assets whose consumption is recorded as consumption of fixed assets' (SNA, 1993, 6.147). FM indicates it 'applies the same treatment [as SNA] to intermediate goods, which are measured by purchases instead of consumption (under heading "other current costs")' (Annex 3).

From an SNA perspective all expenditure under the 'other current category' should not be considered as intermediate consumption because 'labour costs provided by staff providing indirect services, such as security and canteen staff' belong to compensation of employees, so need to be capitalised. However other components fall under the intermediate consumption definition of NA-like purchases of goods and services from outside the unit, including overseas purchases, and scientific services and other overhead costs including, for example security, insurance, storage and computer services (OECD 2002, p 109).

These expenditures are IC.

Practically, the calculation of IC is not easy for two reasons. Firstly, FM data aggregates all expenditures in 'other current' category, but it does not provide information on what has been consumed during the current period and what remains in inventories. SNA focuses upon the cost of inputs actually consumed not bought during this period, as the OECD (2009) indicates that any change in inventories is very likely to be insignificant and can be ignored. Secondly, since firms report an aggregate figure for expenditures on the 'other current' expenditure category therefore it is difficult to separate the components that need to be expensed. Consequently, a total figure for IC is deducted, it includes IC of R\&D which is explained in detail below.

Intermediate consumption of R\&D From NA perspective R\&D inputs in the production of other R\&D assets are a clear case of intermediate consumption. For instance the R\&D sector buys R\&D, 
incorporates it in its products and sells the products in the market. Therefore the purchased R\&D becomes IC of R\&D.

OECD (2009) recommends that:

\section{All expenditures on purchases of R\&D or on R\&D production by market producers in the Scientific Research and Development industry (Division 72 ISIC Rev. 4) should be recorded as intermediate consumption, or otherwise expensed, on the presumption that such units produce R\&D for sale, and any purchases are incorporated in products for sale. Only when specific information is available to the contrary should acquisitions of R\&D be recorded as gross fixed capital formation, such as cases when a unit takes out a patent and sells licences to use.}

For the non-market sector, IC is only recorded when purchased R\&D does not bring the expected benefits. No separate information is available for such $R \& D$ and $\mathrm{R} \& \mathrm{D}$ services consumed in the production of $\mathrm{R} \& \mathrm{D}$, therefore an aggregate adjustment has been made. This adjustment also includes IC of other goods and services, as discussed above. This adjustment is not satisfactory and ideally should be presented separately, but the existing data limit our options. A ratio of intramural R\&D undertaken in the R\&D sector (SIC 73) to total intramural R\&D undertaken in the $R \& D$ sector (from BERD) is used as the basis of this adjustment. However, more detailed data are required to provide better estimates of IC in different cases.

\section{R\&D depreciation rates}

Capitalisation converts R\&D expenditure into an asset, which provides the owner with benefits for more than one period. Therefore benefits remaining at the end of each period need to be calculated. The calculation of these benefits depends heavily on determining the total life length of the asset. Since calculating benefits at the end of each period is costly, a depreciation rate is applied to deduct the benefits received from an asset for the given year. Research on R\&D uses four main methods to determine life length and depreciation rate: a) production function approach, b) amortization models, c) patent renewal method, and d) market valuation method (Mead, 2007). Results from these studies are sensitive to the underlying assumption and different studies conclude conflicting results. Recently Germany, Israel, and the UK have conducted pilot surveys and asked the managers of businesses to report on the life length of various $R \& D$ assets.
The UK survey results will be available next year and will provide better estimates on $\mathrm{R} \& \mathrm{D}$ assets' life lengths. Until then, following Galindo-Rueda (2007) and other countries, we are using geometric depreciation rates of 20 per cent for the market sector. The nonmarket sector rate has been adjusted upward, increased from 5 per cent to 15 per cent, which is similar to the depreciation rate used by other countries.

The two sectors are differentiated to account for the different types of R\&D they undertake. Performance data show that government performs more $R \& D$ in the 'basic research' and 'applied research' category (see Table 3). Contrarily, businesses perform less basic research and focus more on 'applied research' or 'experimental development'. It is commonly accepted that basic research has longer useful life therefore non-market sector R\&D assets depreciate slower.

\section{Measurement of R\&D capital stocks}

The direct measurement of R\&D stock is difficult because of a large share of own account production. In the SNA framework production for own final use is measured as a sum of: intermediate consumption, compensation of employees, consumption of fixed capital, and other taxes less subsidies on production. In the R\&D satellite account the accumulated costs are calculated through the perpetual inventory method (PIM). Three major steps are involved: a) determination of initial capital stock, b) calculation of R\&D capital stock, and c) capital services or capital consumption.

Initial capital stock is important because it affects current capital stock until it is depreciated completely. Galindo-Rueda (2007) estimated initial capital stock with a long term growth rate, and a depreciation rate. The initial stock value is sensitive to the depreciation and growth rate, resulting in uncertainty about its accuracy. We have used published and unpublished data to improve the initial capital stock. For the business sector overall expenditure on R\&D is available from 1966, with the exception of a few missing years. We have used this data for the calculation of historical capital stock through PIM.
For the non-market sector investment data are available only from 1985 . Since a life length of 13 years is assumed we have used an initial stock, calculated using annual investment growth rate and depreciation. Subsequently, we used PIM to derive capital stock data. Using historical investment data reduces the uncertainty related to initial capital stock as well as other capital stock data.

The final step is to calculate R\&D capital services and consumption of R\&D capital, which need to be derived from the stocks of the different sectors. For the non-market sector these two are the same as they consist purely of depreciation. For business, capital services include a rate of return and capital gain.

\section{Capitalisation results}

Adding R\&D to the group of recognised intangible assets increases 'total GFCF, gross operating surplus (GOS), output, gross value added (GVA), gross domestic products (GDP), and net worth' (Aspden, 2005). Most previous studies however indicate little impact on GDP growth. Having laid out the major challenges and improvements in the methodology we can now focus on the results of $R \& D$ capitalization.

\section{GERD to GDP}

The GERD to GDP ratio is an indicator of $\mathrm{R} \& \mathrm{D}$ intensity. It captures the contribution of R\&D to the economy as a whole and is thus an indicator of the impacts of R\&D capitalization on GDP and investment. As a result of capitalising R\&D, the GERD to GDP ratio is consistently shifted downwards by 0.03 per cent. It varies around 1.75 per cent, which is close to the OECD average and comparable to countries such as Canada, the Netherlands and Australia (OECD, 2007). There is no discernible trend in the observed time period and the ratio is still some way off the 2.5 per cent goal set by the government's Science and Innovation Investment Framework 2004-2014 and the 3 per cent target of the European Union.

Figure 1 shows GERD to GDP ratios, which do not fluctuate over time. A similar trend is obvious from the $\mathrm{R} \& \mathrm{D}$ expenditure share of the business, government and NPISH.

\section{Table 3}

\section{$R \& D$ expenditure on types of $R \& D, 2007$}

\begin{tabular}{lrr} 
& & Percentages \\
\hline Basic Research & Business & Government \\
Applied Research & 7 & 49 \\
Experimental Development & 36 & 33 \\
\hline
\end{tabular}




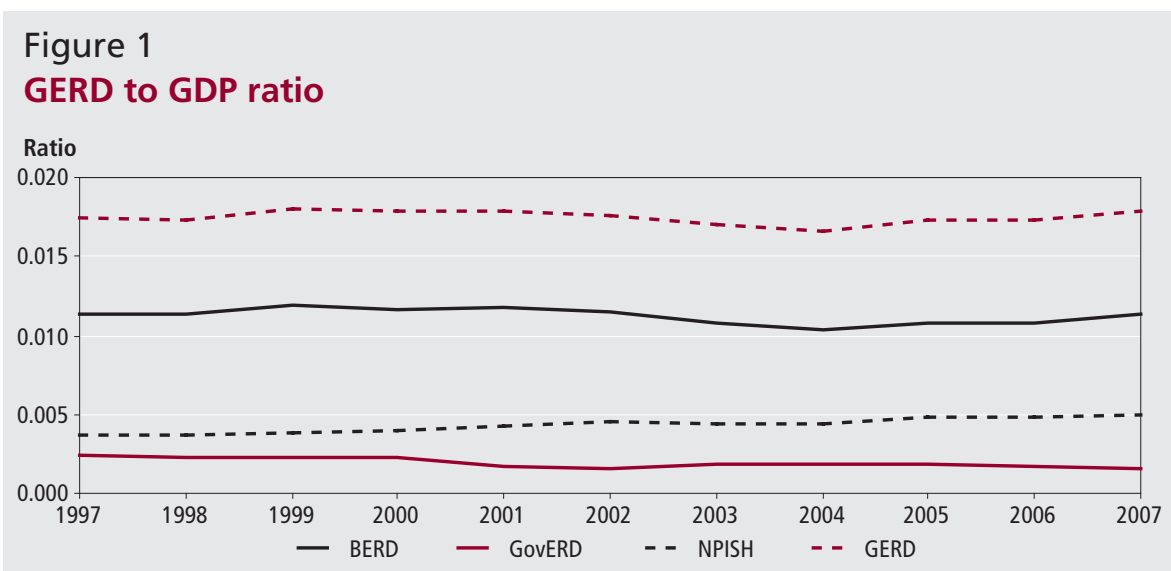

Source: GERD data

Table 4

\section{Estimation of R\&D output, 2007}

\begin{tabular}{|c|c|c|c|c|}
\hline & & & & million \\
\hline & Business & Government & NPISH & Total \\
\hline Starting point: Frascati Manual intramural R\&D expenditure & 16,110 & 2,238 & 7,075 & 25,423 \\
\hline less software adjustment & 733 & 0 & 0 & 733 \\
\hline plus adjustment for tangible fixed assets & 836 & 20 & 64 & 919 \\
\hline plus intermediate consumption (IC) of $R \& D$ in production of $R \& D$ & 125 & 17 & 55 & 197 \\
\hline less subsidies on production & 762 & & & 762 \\
\hline plus taxes less subsidies on R\&D services & 564 & & & 564 \\
\hline Total Supply & 16,140 & 2,275 & 7,194 & 25,609 \\
\hline
\end{tabular}

Source: Authors' calculation based on ONS data

Table 4 summarises the calculation of total R\&D output for 2007. The total R\&D output for the UK has been $£ 25$. 6 billion, roughly two thirds of which occurred in the market sector. The large contribution of NPISH is due to higher education which accounts for more than 90 per cent of its $\mathrm{R} \& \mathrm{D}$ output. The government share is relatively low as it funds significant amounts of $\mathrm{R} \& \mathrm{D}$, but performs relatively little.

Ownership assumptions are used to attribute expenditure to the uses of different sectors. Table 5 shows R\&D Uses in the UK economy from 1997 to 2007. It shows that uses, and hence supply, have increased steadily throughout the past decade, growing on average at 6 per cent per year. Government uses have remained steady during this time period while NPISH has increased its uses to about 20 per cent of the total in 2007.

Comparison with Blue Book (BB) data In order to calculate the impact caused by the capitalization of $R \& D$ it is necessary to compare the figures from the satellite account with those published in the BB. To do so, BB data on R\&D output and intermediate consumption need to be split into institutional sectors. Previously constant employment shares were used to slice the BB data. The use of sector employment shares is not entirely satisfactory because employment shares are based on the total number of employees in each of the sectors.

This is not representative of the labour actually employed in the performance of $R \& D$ and even less of the amount of $R \& D$ performed. Similarly, the shares may vary due to changes in economic conditions therefore the shares should account for this change. We have replaced the constant employment shares with R\&D performance shares from GERD. Now the share of R\&D performed in each sector form the basis of the split of BB data. These shares are calculated annually and attribute on average 64 per cent of R\&D to business enterprises, 25 per cent to NPISH and 11 per cent to government.

\section{Double Counting of Other Goods and Services}

Table 6 shows the impact of the new measurement approach by contrasting new output estimates with those published in the $\mathrm{BB}$. $\mathrm{BB}$ data is disaggregated using the $R \& D$ performance shares described earlier. Since the business sector was previously not valued at cost, business output more than doubles as a result of including own account $\mathrm{R} \& \mathrm{D}$.

However, the difference in the nonmarket sector requires an explanation, since the non-market sector was previously valued at cost and thus already included own account $\mathrm{R} \& \mathrm{D}$. The main reason is the broad coverage of $\mathrm{R} \& \mathrm{D}$ activity. The non-market sector shows significant changes because the FM definition of $\mathrm{R} \& \mathrm{D}$ is broader than the SNA definition, used in the BB. This would mean that more activities are now considered R\&D. However, these newly included expenses were previously captured in expenditure on

\section{Table 5}

\section{R\&D uses}

\begin{tabular}{|c|c|c|c|c|c|c|c|c|c|c|c|}
\hline & & & & & & & & & & & million \\
\hline & 1997 & 1998 & 1999 & 2000 & 2001 & 2002 & 2003 & 2004 & 2005 & 2006 & 2007 \\
\hline Total Uses (= Total Resources) & 15,911 & 16,725 & 18,161 & 19,153 & 20,007 & 21,583 & 22,485 & 23,329 & 26058 & 27,803 & 29,717 \\
\hline Used by Corporations & 8,695 & 8,911 & 9,796 & 10,300 & 10,368 & 10,897 & 11,076 & 12,048 & 13,406 & 14,917 & 15,903 \\
\hline GFCF & 8,382 & 8,565 & 9,348 & 9,872 & 9,927 & 10,451 & 10,672 & 11,837 & 13227 & 14,795 & 15,778 \\
\hline IC & 313 & 346 & 448 & 428 & 441 & 446 & 404 & 211 & 179 & 122 & 125 \\
\hline Used by Government & 2,718 & 2,730 & 2,783 & 2,955 & 2,534 & 2,571 & 3,260 & 3,463 & 3,499 & 3,505 & 3,614 \\
\hline GFCF & 2,652 & 2,660 & 2,701 & 2,872 & 2,468 & 2,508 & 3,193 & 3,427 & 3,469 & 3,485 & 3,597 \\
\hline IC & 65 & 70 & 83 & 83 & 66 & 63 & 67 & 36 & 30 & 19 & 17 \\
\hline Used by NPISH & 2,513 & 2,669 & 2,902 & 3,282 & 3,714 & 4,219 & 4,303 & 4,473 & 5,045 & 5,444 & 5,882 \\
\hline GFCF & 2,410 & 2,556 & 2,760 & 3,134 & 3,553 & 4,041 & 4,137 & 4,383 & 4,966 & 5389 & 5,827 \\
\hline IC & 103 & 113 & 142 & 148 & 161 & 178 & 166 & 90 & 79 & 55 & 55 \\
\hline Uses by RoW (exports) & 1,986 & 2,415 & 2,679 & 2,616 & 3,391 & 3,896 & 3,846 & 3,345 & 4,107 & 3,937 & 4,318 \\
\hline
\end{tabular}


Table 6

Difference in R\&D output measures, 2007

\begin{tabular}{lrrr} 
& & $\mathrm{f}$ million \\
\hline Business & Satellite Account & Blue Book & Difference \\
Government & 17,100 & 6,828 & 10,272 \\
NPISH & 2,275 & 949 & 1,327 \\
\hline
\end{tabular}

Source: Authors' calculation based on ONS data

Table 7

Summary of impact on goods and services account, 2007

\begin{tabular}{lrrr} 
& & $\mathbf{f}$ million \\
\hline Resources & & Uses & \\
\hline R\&D output & 15,794 & R\&D IC & $-7,468$ \\
Other output (non-market Capital Services) & 8,084 & Other IC (double counting) & $-1,457$ \\
Other output (double counting) & $-9,715$ & Exports (adjustment) & $-1,205$ \\
Imports (adjusted) & 321 & Gov FC (services) & 3,488 \\
& & Gov FC (Reclassified) & $-1,984$ \\
& & NPISH FC (services) & 4,596 \\
& & NPISH FC (Reclassified) & $-6,273$ \\
& & NPISH R\&D FC (elim) & -332 \\
& & R\&DGFCF & 25,202 \\
& & Inventories (elmination) & -83 \\
Total Supply R\&D & 16,114 & Total Demand R\&D & 16,114 \\
Total Supply Other Godds \& Servcies & $-1,631$ & Total Demand OGS & $-1,631$ \\
Total resources & 14,484 & Total Uses & 14,484 \\
\hline
\end{tabular}

Source: Authors' calculation based on ONS data

Table 8

Impact of capitalisation on GDP

\begin{tabular}{lrrrrr} 
& \multicolumn{3}{c}{} & f million \\
\hline & GDP (BB) & $\begin{array}{r}\text { GDP Including } \\
\text { Business Sector } \\
\text { R\&D }\end{array}$ & $\begin{array}{r}\text { Per cent } \\
\text { increase }\end{array}$ & $\begin{array}{r}\text { GDP Including } \\
\text { all sectors GDP }\end{array}$ & $\begin{array}{r}\text { Per Cent } \\
\text { Increase }\end{array}$ \\
\hline 1997 & 830,094 & 838,955 & 1.07 & 843,956 & 1.67 \\
1998 & 879,102 & 888,060 & 1.02 & 892,958 & 1.58 \\
1999 & 928,730 & 938,233 & 1.02 & 943,231 & 1.56 \\
2000 & 976,533 & 986,607 & 1.03 & 991,837 & 1.57 \\
2001 & $1,021,828$ & $1,032,108$ & 1.01 & $1,037,554$ & 1.54 \\
2002 & $1,075,564$ & $1,086,457$ & 1.01 & $1,092,041$ & 1.53 \\
2003 & $1,139,746$ & $1,150,871$ & 0.98 & $1,156,693$ & 1.49 \\
2004 & $1,202,956$ & $1,214,323$ & 0.94 & $1,220,851$ & 1.49 \\
2005 & $1,254,058$ & $1,266,985$ & 1.03 & $1,274,241$ & 1.61 \\
2006 & $1,325,795$ & $1,339,958$ & 1.07 & $1,347,856$ & 1.66 \\
2007 & $1,398,882$ & $1,413,886$ & 1.07 & $1,421,970$ & 1.65 \\
\hline
\end{tabular}

Source: Authors' calculation based on ONS data

Table 9

\section{Impact on investment}

\begin{tabular}{lrrr} 
& & \multicolumn{1}{c}{ million } \\
\hline 1997 & BB GCF & Augmented GCF & Per cent increase \\
1998 & 138,307 & 150,805 & 9.04 \\
1999 & 155,997 & 169,018 & 8.35 \\
2000 & 161,722 & 175,500 & 8.52 \\
2001 & 167,172 & 181,999 & 8.87 \\
2002 & 171,782 & 186,777 & 8.73 \\
2003 & 180,551 & 197,009 & 9.12 \\
2004 & 186,700 & 203,945 & 9.24 \\
2005 & 200,415 & 219,066 & 9.31 \\
2006 & 209,758 & 229,299 & 9.32 \\
2007 & 227,370 & 248,936 & 9.48 \\
\hline
\end{tabular}

Source: Authors' calculation based on ONS data
non-R\&D goods and services. Therefore it is necessary to make an adjustment to the non-R\&D side of the NA. Further research will be necessary to investigate the exact nature of the double counting and making adjustment accordingly.

Table 7 indicates the adjustment for the non-market sector as well as other impact on the goods and services account. The net impact of the capitalization is that R\&D supply increases by $£ 16$ billion, while other goods and services is reduced by $£ 1,631$ million.

\section{Capitalisation Impact on GDP}

The main effect of capitalisation is on GDP as the classification of R\&D has changed from intermediate consumption to capital. This implies a reduction in intermediate consumption and an increase in gross value added. Table 8 shows that the capitalisation of R\&D increases GDP by 1.6 per cent, on average, roughly two thirds of which can be attributed to the market sector. This increase is slightly higher than GalindoRueda's (2007) estimate of 1.5 per cent. This is due to the changes in methodology outlined earlier as well as data revisions. The increase in GDP is comparable to the one observed in Canada, 1.6 per cent for 2004, (Statistics Canada, 2008) which has a similar GERD to GDP ratio.

\section{Impact on investment}

Another interesting policy question is the change in investment due to $R \& D$ capitalisation. Total national investment should increase as a result since $\mathrm{R} \& \mathrm{D}$ expenditures are now investment in $R \& D$ assets. Table 9 shows that on average investment increases by 9 per cent as a result of capitalising R\&D. It is important to consider that capital expenditure in $R \& D$ production needs to be removed from the overall GFCF estimates to avoid double counting when deriving the augmented GFCF.

\section{Conclusion}

$R \& D$ creates new products and resources for the future. As a result it becomes one of the determinants of firm productivity and long term economic growth. If $R \& D$ is classified as intermediate consumption or not recoded as an asset in the NA it understates the national investment, net wealth and savings. This article is another contribution to the R\&D capitalisation agenda and shows how capitalisation can be achieved, and the effect upon NA aggregates.

This updated account has made several changes to the capitalisation methodology. Firstly, the depreciation rate for non-market $\mathrm{R} \& \mathrm{D}$ has been increased from 5 per cent to 
15 per cent. Secondly, the L\&B deflator is replaced with a more appropriate deflator from NA, and 'other current' expenditure deflator weights have been updated based on expenditure data. Thirdly, the constant inflation component of nominal rate-ofreturn is replaced with a three year moving average derived from the Consumer Price Index (CPI). The allocation of Blue Book data is now based on shares of $\mathrm{R} \& \mathrm{D}$ performed in the market and nonmarket sectors than employment shares from Interdepartmental Business Register (IDBR).

Capitalising R\&D produces several changes in the NA. GDP increases modestly, by 1.6 per cent, on average, and GCF goes up by 9 per cent. Total R\&D output increased by 6 per cent from 1997 and total $\mathrm{R} \& \mathrm{D}$ output is $£ 25.6$ billion in 2007 . This however has not changed the GERD to GDP ratio substantially. Capitalisation also has other downstream effects eg a decrease in non-market sector's consumption, an increase in property income for the business sector, among others.

Several areas have been identified for future improvements. These include: integrating life lengths information from a new survey on Investment in Intangible Assets; gathering further information on the magnitude of the software overlap; refining ownership assumptions; deriving capital services for non-market sector from GovERD data; adjustment for work in progress, inventories and possibly time lags; and further investigation on the nature of double counting in the non-market sector as well as the treatment of international $\mathrm{R} \& \mathrm{D}$.

\section{Notes}

1 For more details on the impact of R\&D in 16 OECD countries see: Lichtenberg and van Pottelsberghe (2001).

2 The name signifies the first meeting of experts on R\&D statistics in June 1963 in Frascati, Italy. The manual covers conceptual and practical issues related to $\mathrm{R} \& \mathrm{D}$, data collection on $\mathrm{R} \& \mathrm{D}$, and wider issues of innovation, and knowledge economy.

3 SNA is an internationally agreed system that provides a coherent framework for recording and presenting the main flow of economic activity.

4 Business, Government, Non-Profit Institutions Serving Households (NPISH), and the Rest of the World (ROW).

5 We have avoided using GFCF, Gross Fixed Capital Formation, because R\&D and other intangibles are not fixed capital. As an alternative we have used GCF, gross capital formation.

6 Other current category includes, 'purchases of goods and services from outside the unit, including overseas purchases, and scientific services ... Administrative and other overhead costs including for example security, insurance, storage and computer services should be recorded here.' (OECD, 2002)

7 This sector includes: 'all universities, colleges of technology and other institutions of post-secondary education, whatever their source of finance or legal status'. It also includes 'all research institutes, experimental stations and clinics operating under the direct control of or administered by or associated with the higher education institutions' (OECD, 2002, p 68).

8 For more detail on linking see: Carol (2006). Allocating HE to NPISH depends on the breakdown between the public and private universities; for example, Canada classifies Higher Education in the general government sector (Statistics Canada, 2008).

9 For definition, see footnote 6.

10 Another issue is the treatment of land. FM includes expenditure on land as part of expenditures on L\&B, but SNA excludes land from the list of assets. We did not adjust for land because disaggregated data are not available.

\section{ACKNOWLEDGEMENTS}

The authors would like to acknowledge dedicated support from Helen Meaker and her team on providing various details on GERD data and meticulously solving data related problem. Similarly, we are grateful to Tony Clayton and Mark Franklin for their overall guidance and taking their time to provide valuable comments on various drafts. Finally, we are thankful to Fernando GalindoRueda and Mathew Powel for taking their time to discuss various capitalisation issues and providing us valuable suggestions.

\section{CONTACT}

国elmr@ons.gsi.gov.uk

\section{REFERENCES}

Aspden, Charles (2005) 'Update of the 1993 SNA-Issue No. 9 and 10, Issue Paper for the Meeting of the AEG, July 2005, Extending the Asset Boundary to Include Research and Development.' Available at:
unstats.un.org/unsd/nationalaccount/AEG/ papers/m3reFsearchDevelopment.pdf

Chamberlin G (2007) 'New measures of UK private sector software investment', Economic \& Labour Market Review, Vol 1, No 5, pp $17-28$.

Dominique Guellec \& Bruno van Pottelsberghe de la Potterie, 2001 'R\&D and Productivity Growth: Panel Data Analysis of 16 OECD Countries,' OECD Science, Technology and Industry Working Papers 2001/3, OECD, Directorate for Science, Technology and Industry.

Evans P, Hatcher M and Whittard D (2008) 'The preliminary R\&D satellite account for the UK: a sensitivity analysis', Economic \& Labour Market Review, Vol 2, No 9, pp 37-43.

Galindo-Rueda F (2007) 'Developing an R\&D satellite account for the UK; a preliminary analysis', Economic \& Labour Market Review, Vol 1, No 12, pp 18-29.

Mead C I (2007) 'R\&D Depreciation Rates in the 2007 R\&D Satellite Account', Available at www.bea.gov/papers/pdf/Mead_RD_Paper_ wp.pdf

OECD (2002) 'Frascati Manual - Proposed Standard Practice for Surveys on Research and Experimental Development', OECD Publications: Paris

OECD (2007) 'Update of the 1993 SNA: Progress report and main issues', Paper presented at the 11th OECD-NBS Workshop on National Accounts, Beijing, September 25-28 2007.

OECD (2009) 'Handbook on deriving Capital Measures of Intellectual Property Products' OECD, Paris.

Carol A. Robbins, 2006 'Linking Frascatibased R\&D Spending to the System of National Accounts,' BEA Working Papers 0035, Bureau of Economic Analysis.

Statistics Canada (2008) 'The Canadian Research and Development Satellite Account, 1997 to 2004 ', Available at:

www.statcan.gc.ca/pub/13-604-m/13-604m2007056-eng.pdf

System of National Accounts (1993) EurostatIMF-OECD-UN-World Bank, Brussels, New York, Washington. Available at: unstats.un.org/unsd/sna1993/toctop.asp

The ONS Productivity Handbook: a Statistical Overview and Guide (2007) The Office for National Statistics, UK. Available at: www.ons.gov.uk/about-statistics/userguidance/productivity-handbook/index.html 